\title{
Photorhabdus adhesion modification protein (Pam) binds extracellular polysaccharide and alters bacterial attachment
}

\author{
Robert T Jones ${ }^{\dagger 1,5}$, Maria Sanchez-Contreras ${ }^{*+1}$, Isabella Vlisidou ${ }^{\dagger 1}$, Matthew R Amos ${ }^{1}$, Guowei Yang ${ }^{1}$, Xavier Muñoz- \\ Berbel2 , Abhishek Upadhyay', Ursula J Potter ${ }^{3}$, Susan A Joyce 1,6, Todd A Ciche4, A Toby A Jenkins², Stefan Bagby?, \\ Richard $\mathrm{H}$ ffrench-Constant ${ }^{1,5}$ and Nicholas R Waterfield 1
}

\begin{abstract}
Background: Photorhabdus are Gram-negative nematode-symbiotic and insect-pathogenic bacteria. The species Photorhabdus asymbiotica is able to infect humans as well as insects. We investigated the secreted proteome of a clinical isolate of P. asymbiotica at different temperatures in order to identify proteins relevant to the infection of the two different hosts.

Results: A comparison of the proteins secreted by a clinical isolate of P. asymbiotica at simulated insect $\left(28^{\circ} \mathrm{C}\right)$ and human $\left(37^{\circ} \mathrm{C}\right)$ temperatures led to the identification of a small and highly abundant protein, designated Pam, that is only secreted at the lower temperature. The pam gene is present in all Photorhabdus strains tested and shows a high level of conservation across the whole genus, suggesting it is both ancestral to the genus and probably important to the biology of the bacterium. The Pam protein shows limited sequence similarity to the $13.6 \mathrm{kDa}$ component of a binary toxin of Bacillus thuringiensis. Nevertheless, injection or feeding of heterologously produced Pam showed no insecticidal activity to either Galleria mellonella or Manduca sexta larvae. In bacterial colonies, Pam is associated with an extracellular polysaccharide (EPS)-like matrix, and modifies the ability of wild-type cells to attach to an artificial surface. Interestingly, Surface Plasmon Resonance (SPR) binding studies revealed that the Pam protein itself has adhesive properties. Although Pam is produced throughout insect infection, genetic knockout does not affect either insect virulence or the ability of $P$. luminescens to form a symbiotic association with its host nematode, Heterorhabditis bacteriophora.

Conclusions: We studied a highly abundant protein, Pam, which is secreted in a temperature-dependent manner in $P$. asymbiotica. Our findings indicate that Pam plays an important role in enhancing surface attachment in insect blood. Its association with exopolysaccharide suggests it may exert its effect through mediation of EPS properties. Despite its abundance and conservation in the genus, we find no evidence for a role of Pam in either virulence or symbiosis.
\end{abstract}

\section{Background}

Photorhabdus bacteria are pathogens of insects, and obligate symbionts with insect-pathogenic Heterorhabditid nematodes $[1,2]$. These host nematodes invade an insect and regurgitate the bacteria from their gut [3]. The bacteria then colonize the infected insect and release both insecticides that kill the insect host and antibiotics to kill

\footnotetext{
* Correspondence: msc23@bath.ac.uk

1 Department of Biology and Biochemistry, University of Bath, Claverton Down, Bath, BA2 7AY, UK

+ Contributed equally

Full list of author information is available at the end of the article
}

any invading and competing microbes [4]. Following several rounds of nematode and bacterial replication, a new generation of infective juvenile (IJ) nematodes re-uptake the bacteria and exit the cadaver to find new hosts [1]. This dual requirement for symbiosis and virulence makes Photorhabdus an excellent model organism for studying bacterial colonization and developmental behaviour in addition to a potential source of potent new insecticidal proteins and antibiotics [2]. The genus Photorhabdus comprises three distinct species: P. temperata, P. luminescens and $P$. asymbiotica. Although all three are highly 
pathogenic to insects, $P$. asymbiotica was originally isolated from human wounds and its nematode vector has only recently been identified [5]. Little is known about transmission into human patients, but $P$. asymbiotica is unique in the genus in being able to grow at $37^{\circ} \mathrm{C}$ and is considered an emerging human pathogen [6]. In an attempt to find potential host-interacting proteins that are relevant to either human or insect infections we used two-dimensional (2D) gel electrophoresis to compare supernatant proteins secreted at $28^{\circ} \mathrm{C}$ and $37^{\circ} \mathrm{C}$. We identified a number of proteins that were differentially produced at these temperatures. Two small proteins were of particular interest, because they were secreted at a very high level at $28^{\circ} \mathrm{C}$ but were not detectable at the clinically relevant temperature of $37^{\circ} \mathrm{C}$. One of these proteins was encoded by a gene on a plasmid found only in P. asymbiotica strains. The other was encoded by a chromosomal gene previously identified in a proteomic study of $P$. luminescens TT01 [7]. We present here the first detailed investigation into the role of this second highly secreted protein present in both $P$. luminescens and P. asymbiotica.

\section{Results}

Identification of Pam by two-dimensional electrophoretic analysis of the P. asymbiotica ATCC43949 secreted proteins Given the availability of P. asymbiotica ATCC43949 genomic sequence and the ability of this strain to grow at both clinically relevant $\left(37^{\circ} \mathrm{C}\right)$ and insect relevant $\left(28^{\circ} \mathrm{C}\right)$ temperatures, we used proteomics to identify secreted proteins that may be important for the two different hosts. Two-dimensional gel electrophoresis of supernatant proteins revealed two small highly abundant proteins (initially designated S1 and S15) that were secreted at $28^{\circ} \mathrm{C}$ but not at $37^{\circ} \mathrm{C}$ (Fig. 1). We compared the MALDI-
ToF profiles of these proteins with a database of all the predicted proteins from the finished $P$. asymbiotica genome sequencing project [8] for their identification. One of these proteins, S1, was found to be encoded by a gene present on the plasmids of clinical $P$. asymbiotica strains but absent from all $P$. temperata and P. luminescens strains so far examined. This plasmid, pPAU1, has homology to the Yersinia pestis pMT1 plasmid, which is essential for vectoring by the flea host. The small S1 protein is similar to the YPMT1.14c hypothetical protein which has a bacterial Ig-like domain (group 2) although its function is not known. The second protein, S15 (renamed Pam: Photorhabdus adhesion modification protein), matched Plu1537 previously identified in proteomic studies of P. luminescens TT01 [7]. In strain TT01, the product of the plu1537 gene is the most highly secreted protein, accounting for more than $30 \%$ of the total extracellular proteins. The P. asymbiotica ATCC43949 homologue is a protein of 136 amino acids with a predicted mass of $14.98 \mathrm{kDa}$ and a calculated isoelectric point of 4.7. Searches of current protein databases show limited similarity to known proteins. The best sequence match is seen between amino acids 19-121 of Pam which show $31 \%$ identity to amino acids $10-111$ of the $13.6 \mathrm{kDa}$ component of a Bacillus thuringiensis binary toxin [9]. Injectable insecticidal activity has been reported for Pit, a protein encoded by the homologous gene of pam in $P$. luminescens subsp. akhurstii strain YNd185 [10]. We used PCR to elucidate the distribution of the $s 1$ and pam genes in the genus Photorhabdus (data not shown). As predicted, the gene encoding S1 was only seen in the plasmid-carrying $P$. asymbiotica isolates and is presumably of relevance only to these strains [8]. An alignment of pam sequences from $P$. asymbiotica ATCC43949 and $P$.

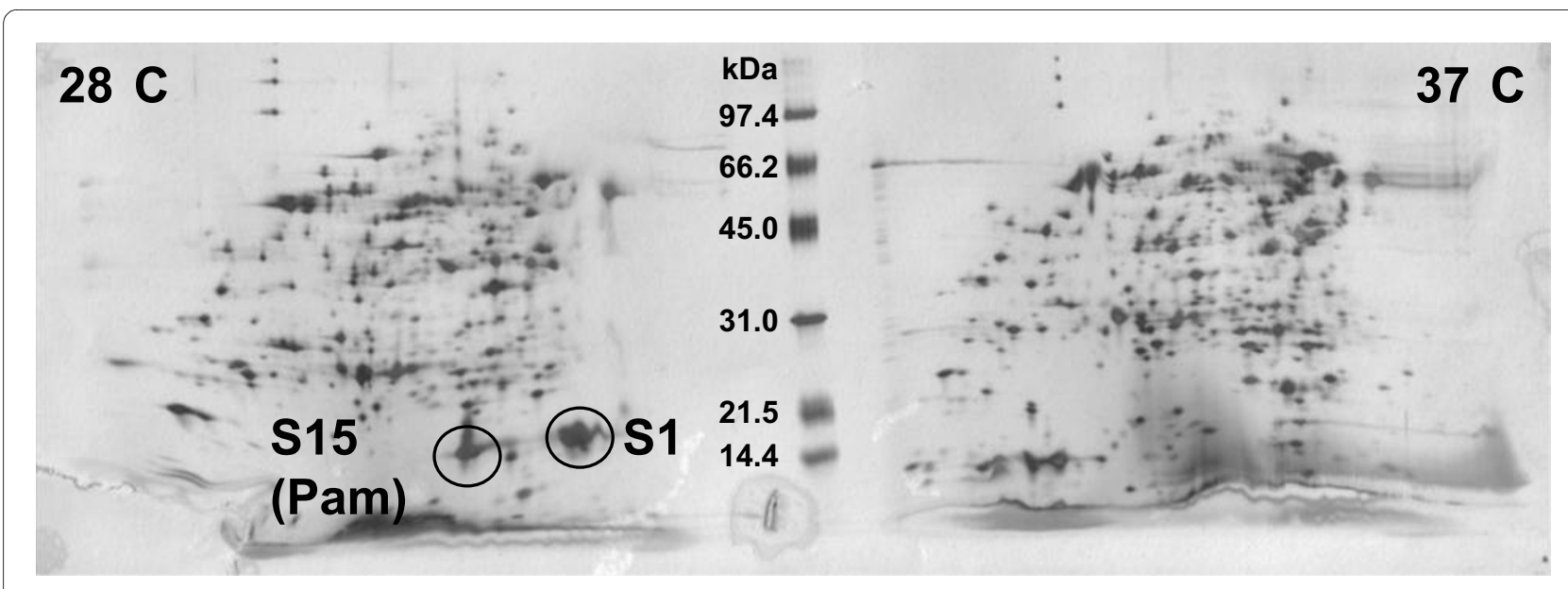

Figure 1 Two-dimensional gel electrophoresis of the secreted proteome of $P$. asymbiotica ATCC43949. Proteins were obtained from supernatants of cultures grown at $28^{\circ} \mathrm{C}$ and $37^{\circ} \mathrm{C}$ and separated first by isoelectric point, along a 3-10 pH gradient, and then by mass. The 2D gel identifies several proteins with differential levels of production in these conditions, including S1 and S15 (circled) which are only secreted at $28^{\circ} \mathrm{C}$ 
luminescens TT01 revealed a high level of DNA homology (87.5\%). We amplified and sequenced pam from 13 other strains of the genus Photorhabdus. Sequence comparison of the predicted proteins revealed very high amino acid conservation, with $89.6 \%$ similarity between even the most diverse sequences. In addition, the inferred phylogeny of the pam genes from different members of the genus follows the same clade-groupings as multilocus sequence typing data [5] suggesting that pam is ancestral to the genus. In order to facilitate further analysis of the Pam protein an antibody was raised to a peptide (KLIQDSIRLDQGEW) conserved in the Pam protein family.

\section{In vivo and in vitro production of Pam}

As the identification of highly-secreted Pam occurred at $28^{\circ} \mathrm{C}$, a temperature relevant to the infection of insect hosts, we monitored Pam production over time in Galleria mellonella larvae injected with either $P$. luminescens TT01 (Fig. 2A) or P. asymbiotica ATCC43949 (Fig. 2B). We observed high levels of production in the insect host at $48 \mathrm{~h}$ post-injection which continued for a further 11 days, suggesting a possible role of this secreted protein in the occupation of the insect cadaver. It is also possible that Pam is produced in the insect before $48 \mathrm{~h}$ and has not been detected with our methods. We were unable to

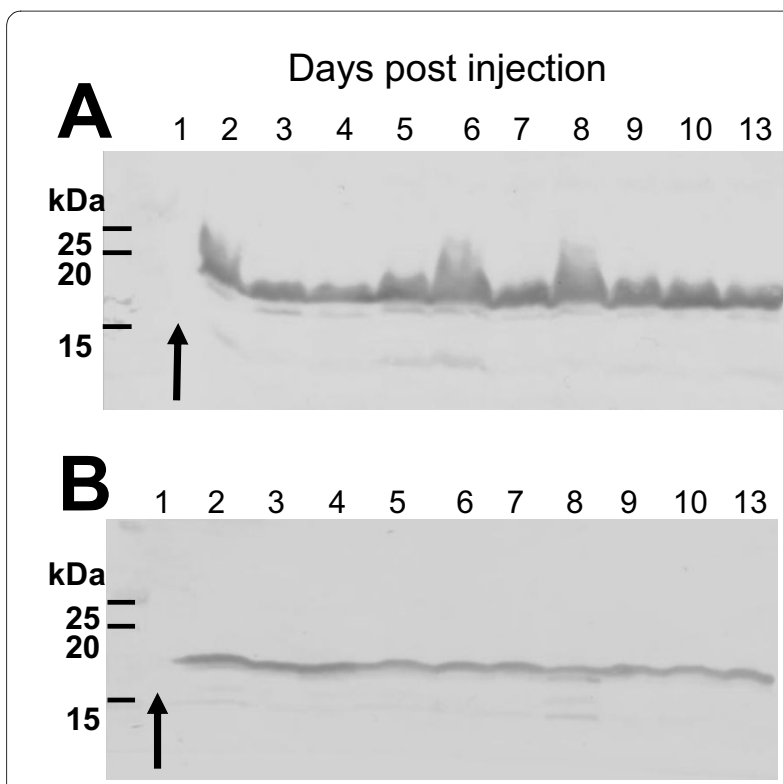

Figure 2 Detection of Pam in infected G. mellonella. Each insect was injected with (A) P. luminescens TT01 or (B) P. asymbiotica ATCC43949, and was frozen and crushed in $1 \mathrm{ml}$ of buffer at days 1 to 10 and 13 post injection. $10 \mu \mathrm{l}$ of each sample was used per lane for SDS-PAGE, and Western blot analysis using anti-Pam antibody showed production from the second day after infection. The arrow indicates that Pam is not produced by Photorhabdus in the first day of G. mellonella infection or that it is below the detection limit of the assay. isolate tissues within the insect for Pam-specific production patterns due to internal disruption of the cadaver 48 $\mathrm{h}$ after infection. In vitro production of Pam was monitored in P. asymbiotica ATCC43949 liquid cultures, and it was first detected in supernatants by Western blot after 6 h 30 min of growth in $\mathrm{LB}$ medium at $28^{\circ} \mathrm{C}$, corresponding to the exponential phase of the culture (Fig. 3A). Pam continued to be produced throughout growth into stationary phase $(48 \mathrm{~h}$ ) and up to 6 day-old cultures (data not shown). As expected, no Pam was released at $37^{\circ} \mathrm{C}$ although cell-associated Pam could be detected, indicating it is synthesized but not released into the surrounding milieu. The fact that Pam protein is released only at insect-relevant temperatures and the difficulties with genetic manipulation and transformation of $P$. asymbiotica strain ATCC43949, led us to make a pam knock-out

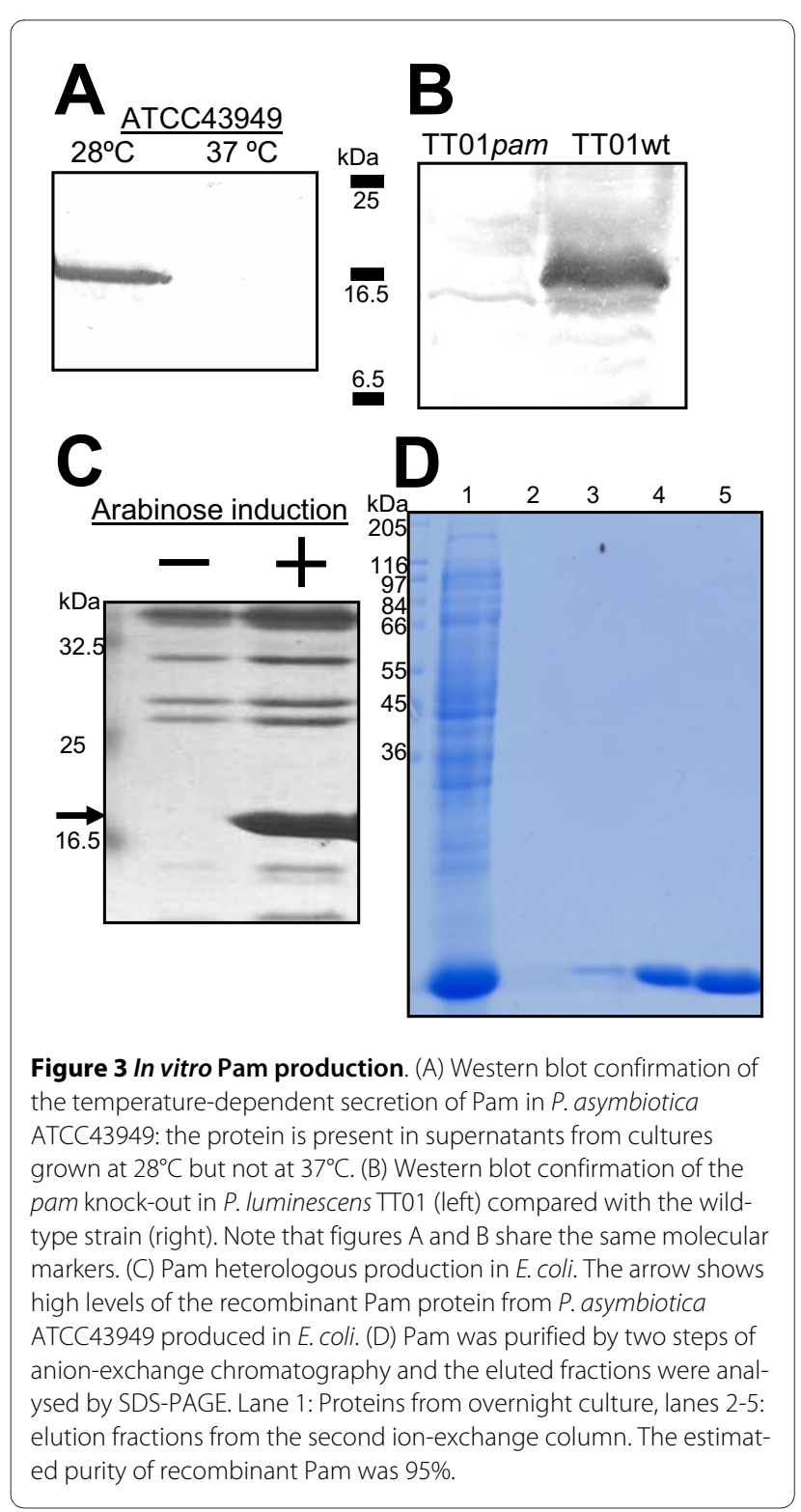


strain in the well-characterized P. luminescens TT01. Figure $3 \mathrm{~B}$ shows a Western blot demonstrating the absence of Pam in the mutant strain TT01pam. For heterologous expression in E. coli, pam was amplified from P. asymbiotica ATCC43949 and cloned in the arabinose-inducible vector $\mathrm{pBAD} 30$, under translational control of its native Shine-Dalgarno region. Heterologous production of Pam was confirmed by Western blot (Fig. 3C). The recombinant protein was purified using ion-exchange chromatography for further analysis (Fig. 3D).

\section{Pam does not influence insect virulence or nematode symbiosis}

Given Pam's similarity to a part of the B. thuringiensis 13.6 kDa Cry toxin and the previous insecticidal studies on the homologous pit from strain YNd185 [10], we tested Pam for toxicity to insects. First, we compared the virulence of the TT01pam strain with the TT01rif parental strain by injection into G. mellonella using standard $\mathrm{LT}_{50}$ assays, where approx 100 cells from a diluted overnight culture were injected per insect, and 100 insect larvae were used per treatment. No significant delay in insect death of the TT01pam strain $\left(\mathrm{LT}_{50}=49.7 \mathrm{~h}\right)$ relative to the TT01rif $\left(\mathrm{LT}_{50}=48.0 \mathrm{~h}\right)$ was observed, indicating that Pam does not play a major role in insect pathogenicity. We also injected G. mellonella and $M$. sexta larvae with a range of dilutions from suspensions of sonicated E. coli cells producing Pam, but we saw no toxicity (data not shown). Finally, to assess oral toxicity, we fed $M$. sexta neonate larvae with suspensions of sonicated cells producing Pam. We observed no significant differences in larval weight gain after one week (expressed in average grams \pm standard error) between $E$. coli expressing pam $(0.1165 \pm 0.005)$, E. coli control carrying the empty vector $(0.0952 \pm 0.009)$ and PBS buffer as control $(0.1154 \pm 0.010)$, indicating that Pam does not cause oral toxicity or delay in feeding in $M$. sexta. Our data suggest no role of Pam in insect virulence under the conditions tested.

We examined the ability of TT01pam to form an effective symbiosis with the host nematode Heterorhabditis bacteriophora. We saw no defect in transmission efficiencies (mean \pm s.e.) of TT01pam $(0.954 \pm 0.023)$ when compared to TT01 wild type $(0.954 \pm 0.025)$. We also observed no significant differences between nematodes carrying TT01pam and those carrying TT01 wild type when we assessed other traits relevant for symbiosis such as: recovery from infective juveniles (IJ stage) to hermaphrodites (adult stage) and development to second generation in vitro, repackaging of the bacteria and infection of G. mellonella with re-coupled EPN-complex and emergence yield (data not shown). The results from all the aspects investigated suggest that Pam is not essential either for the symbiotic stage of the Photorhabdus lifecycle or for pathogenic activity in the insect.

\section{Pam binds to EPS in the extracellular matrix and modifies cell attachment}

To investigate the localization of Pam in P. luminescens TT01 cells, sections of bacterial colonies were observed under transmission electron microscopy (TEM) revealing large amounts of exopolysaccharide (EPS)-like matrix filling the spaces between cells (Fig. 4A). We used immunogold localization of Pam in these sections and found that the protein is associated with this extracellular material that is distributed surrounding the cells (Fig. 4B). In TT01pam the EPS-like material was still present but we did not see specific binding of the antibody (Fig. 4C), suggesting that although Pam binds to the extracellular matrix, it does not significantly alter its production or general structure. Furthermore, Western-blot analysis using the anti-Pam antibody revealed that Pam could be detected in crude EPS preparations (Fig 4D), confirming that from all the extracellular matrix components Pam binds at least to EPS. Our studies revealed that EPSbound Pam can be released by the action of SDS and salt (KCl) but not by mechanical disruption (vortex) (data not shown).

As Pam binds to EPS and EPS has been shown to be important in biofilm formation [11], we investigated the possibility that Pam influences the different stages of biofilm formation. Pellicle assays and biofilm growth in microscopy chambers did not show differences in mature biofilm formation between TT01rif and TT01pam (data not shown). To analyze the influence of Pam on the early steps of biofilm formation, namely initial attachment, we looked at attachment of the two strains to glass coverslips when cultured ex vitro in hemolymph plasma. As shown in Figure 5, the parental TT01rif cells attached in greater numbers than TT01pam to the glass surface in hemolymph, but not in LB medium or Schneiders insect growth medium (data not shown). Importantly, we were also able to detect Pam in cell and supernatant fractions in bacteria grown in hemolymph plasma at 8 hours.

To study in more detail the role of Pam in attachment and its adhesive properties, we used surface plasmon resonance (SPR) to measure binding to an abiotic gold surface. First, we used washed cells in an attempt to assess the role of Pam when it is bound to the EPS surrounding the bacterium: TT01pam showed increased binding to the surface compared to the parental TT01rif (Fig. 6A), indicating that the presence of the protein reduces adhesion to the surface in these conditions. Similarly, in Pamexpressing $E$. coli we observed a decrease in adhesion compared to E. coli control (Fig. 6B). Using SPR to assess the effect of Pam secreted into the medium, we analyzed the supernatants of cultures. In this case we found the 


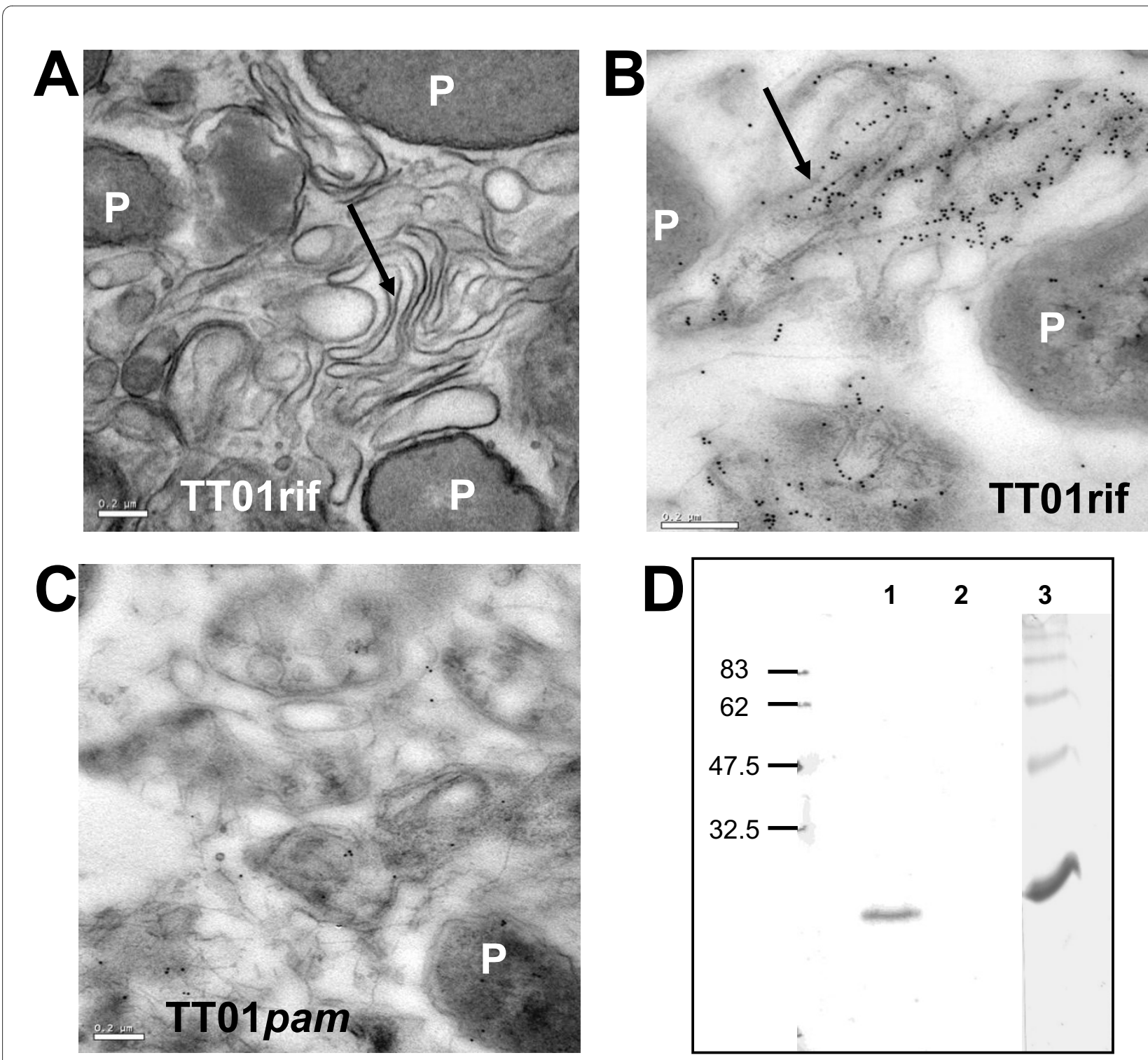

Figure 4 Pam localization on bacterial cells. (A) Micrograph of a cross-section from a P. luminescens TT01 colony observed by TEM. Note the presence of an extensively folded extracellular matrix (black arrow) between the bacterial cells (indicated with P). (B) Immunolocalization of Pam using the anti-Pam antibody and a conjugated-gold secondary antibody. Gold particles extensively decorate the fibrillar EPS-like matrix (black arrow). (C) The TT01pam strain shows no anti-Pam antibody signal but the fibrillar matrix is still present. Scale bars are $0.2 \mu \mathrm{m}$. (D) Western blot confirming the presence of Pam in preparations of crude EPS. Lane 1: crude EPS extracted from TT01 rif, lane 2: EPS from TT01 pam and lane 3: purified recombinant Pam.

opposite effect: when Pam, either from TT01rif or recombinant $E$. coli cultures, was secreted in the supernatant we observed a greater change in SPR angle, indicating that in the presence of Pam more material bound to the gold surface than from the supernatant of cells lacking Pam, TT01pam and control E. coli (Figs. 6C and 6D). We checked that this effect was due specifically to the presence of Pam in the supernatant by blocking Pam binding with addition of the anti-Pam antibody (X. Muñoz-Berbel, M. Sanchez-Contreras and A. T. A. Jenkins, unpublished data). These results suggest that secreted Pam binds to surfaces, while when Pam is bound to the cell surface it makes these cells less able to attach.

\section{Structural studies of Pam}

In order to better understand the physicochemical properties that confer on Pam the ability to bind EPS and influence cell attachment, we investigated the structural properties of the protein by circular dichroism (CD) spectroscopy and differential scanning calorimetry (DSC). CD spectra at near-UV and far-UV wavelengths were obtained for purified heterologously produced Pam. 


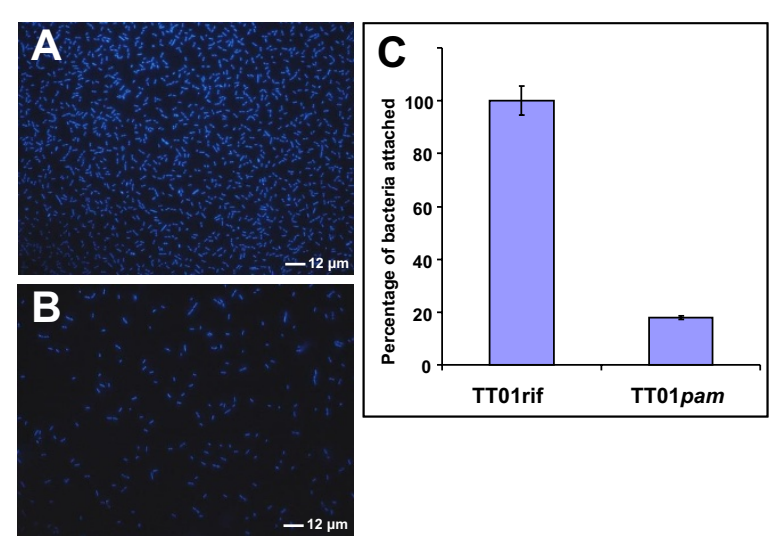

Figure 5 Comparison of bacterial attachment to surfaces in presence of insect hemolymph by fluorescence microscopy between TTO1 rif and the pam mutant. Cells were grown on glass coverslips at $28^{\circ} \mathrm{C}$ for 8 hours. Planktonic bacteria were washed off and adherent bacteria were fixed and stained with DAPI. The adherence of TT01 pam (B) is presented as a percentage of the data determined for the corresponding parental strain TT01 rif (A). Bacterial counts were performed at $60 \times$ magnification and the data represent the mean values of 12 fields from triplicate experiments ( \pm St.Dev) (C)

Weak spectra were recorded in the near-UV, but a strong signal was obtained between $182 \mathrm{~nm}$ and $240 \mathrm{~nm}$ in the far-UV range. A large positive maximum at $192 \mathrm{~nm}$ and negative maxima at $208 \mathrm{~nm}$ and $222 \mathrm{~nm}$ indicate that the secondary structure of the protein is largely $\alpha$-helical [12]. Analysis of the spectra using the CDSSTR variable selection method gave secondary structure estimates of $58 \%$ helix, $8 \%$ strand, $16 \%$ turns and 18\% unordered structure. The normalized root mean standard deviation (NRMSD) for the estimates provides a goodness-of-fit measure of the correspondence between the experimental and calculated spectra (Fig. 7A); we obtained a NRMSD value of 0.011 , which suggests a very accurate prediction of the secondary structure. However, this prediction depends ultimately on how closely the reference dataset proteins used to derive the calculated spectra share structural similarity to Pam [13].

The temperature stability of Pam was measured using DSC. Energy changes in purified recombinant protein were recorded as the sample was heated at a constant rate from $20^{\circ} \mathrm{C}$ to $95^{\circ} \mathrm{C}$. The sample was then allowed to cool before the analysis was repeated. The thermal transition curve measured for Pam reveals two things: firstly, the protein is relatively thermostable, not undergoing a change in enthalpy until the temperature of the system was above $60^{\circ} \mathrm{C}$, and reaching a transition midpoint at $77.4^{\circ} \mathrm{C}$. Above this midpoint, energy is released and the thermal profile drops toward the baseline (Fig. 7B). Secondly, upon reheating Pam follows a similar profile, except for a slight shoulder between approximately $60^{\circ} \mathrm{C}$ and $70^{\circ} \mathrm{C}$. This shoulder is indicative of misfolding, with the protein not making all of its native contacts, but its magnitude suggests that the protein was largely able to refold to its original conformation and unfold at a rate identical to that measured in the first scan.

\section{Discussion}

We have studied a previously identified protein (Plu1537, here renamed Pam) which in P. asymbiotica ATCC43949 is secreted in a temperature-dependent manner, suggestive of a host-specific role in insects. In the closely related insect-only pathogen $P$. luminescens TT01, Pam has been estimated to constitute more than $30 \%$ of total secreted protein [7], potentially indicating an important role in the lifestyle of this bacterium. Further sequence alignment and the inferred phylogeny of the pam genes from different Photorhabdus species suggest that pam is both ancestral and conserved throughout the genus. Where variable regions in amino acid sequence do exist, they could therefore be responsible for determining functional specificity of the protein within strains.

Given the characteristic dual lifecycle of Photorhabdus, with both a nematode-symbiotic and a insect-pathogenic stage, the limited similarity of Pam with B. thuringiensis Cry34 insecticidal protein, and the previous insecticidal studies with Pit [10], the first phenotypes tested with the pam mutant were toxicity to insects and symbiotic efficiency with the bacterium's partner nematode $H$. bacteriophora. Interestingly, the deletion of the pam gene did not affect the ability of $P$. luminescens TT01 to support nematode growth, the production of infective juveniles, re-association of the bacteria with the worm or their ability to re-infect an insect. Similarly, we were not able to demonstrate any difference in insect survival (measured by $\mathrm{LT}_{50}$ ) when $\mathrm{G}$. mellonella were injected with wild-type or pam mutant strains, but this could result from the high redundancy of virulence factors in Photorhabdus [14]. In the case of Pam recombinant protein, which did not cause toxicity either by injection or feeding assays, it is possible that Pam is not toxic by itself but requires a second, as yet unidentified, protein partner that operates in a binary toxin-type system. The closest known homolog of Pam is the $13.6 \mathrm{kDa}$ Cry34 protein from B. thuringiensis, which only exerts effective mortality when coupled with its partner Cry35 $[15,16]$. The precise mode of action of Cry34 toxins remains unclear, but susceptible insects show histopathological symptoms in the midgut epithelium, characterized by cell blebbing and vacuolation [9]. We have not found any genes in Photorhabdus that are predicted to encode a component similar to Cry35. It should be noted that our findings are contrary to reports of toxicity of purified Pam protein by $\mathrm{Li}$ and co-workers [10]. It is possible that the Pam variant they produced (Pit) as a GST-fusion from P. luminescens subsp. akhurstii YNd185, either has a much greater inherent toxicity to $G$. 


\section{A}
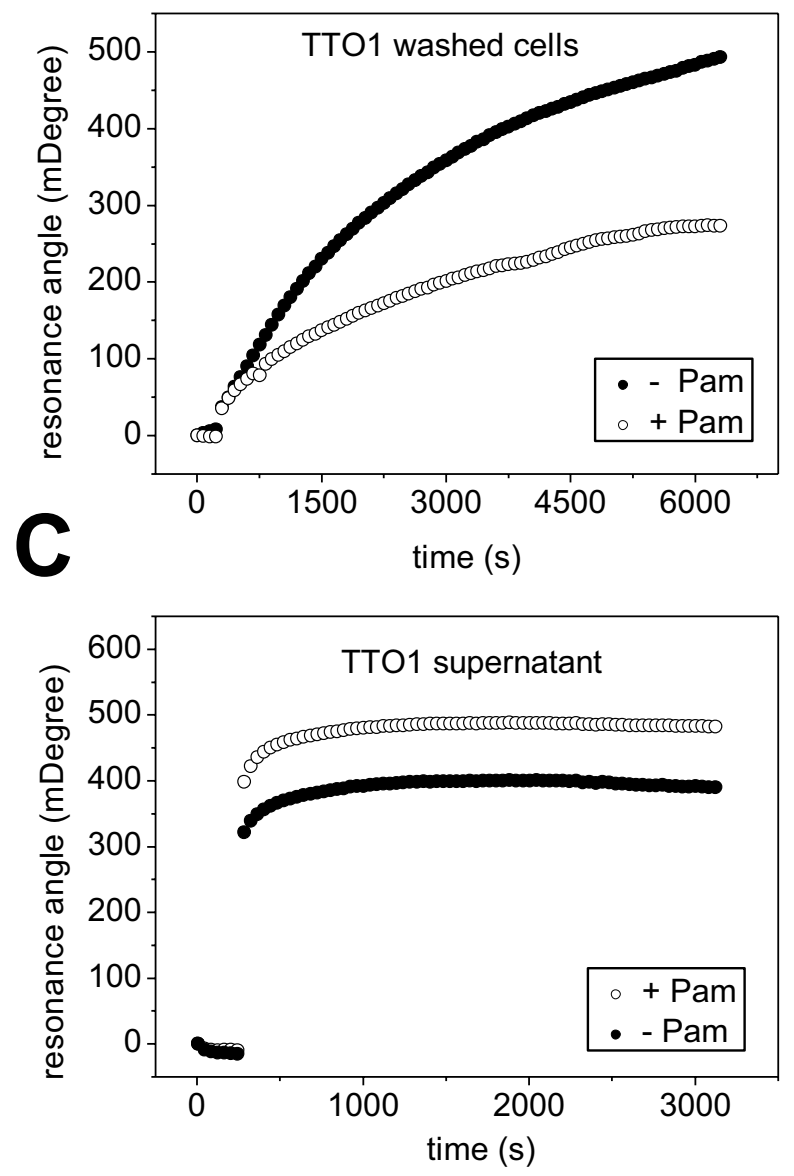

B
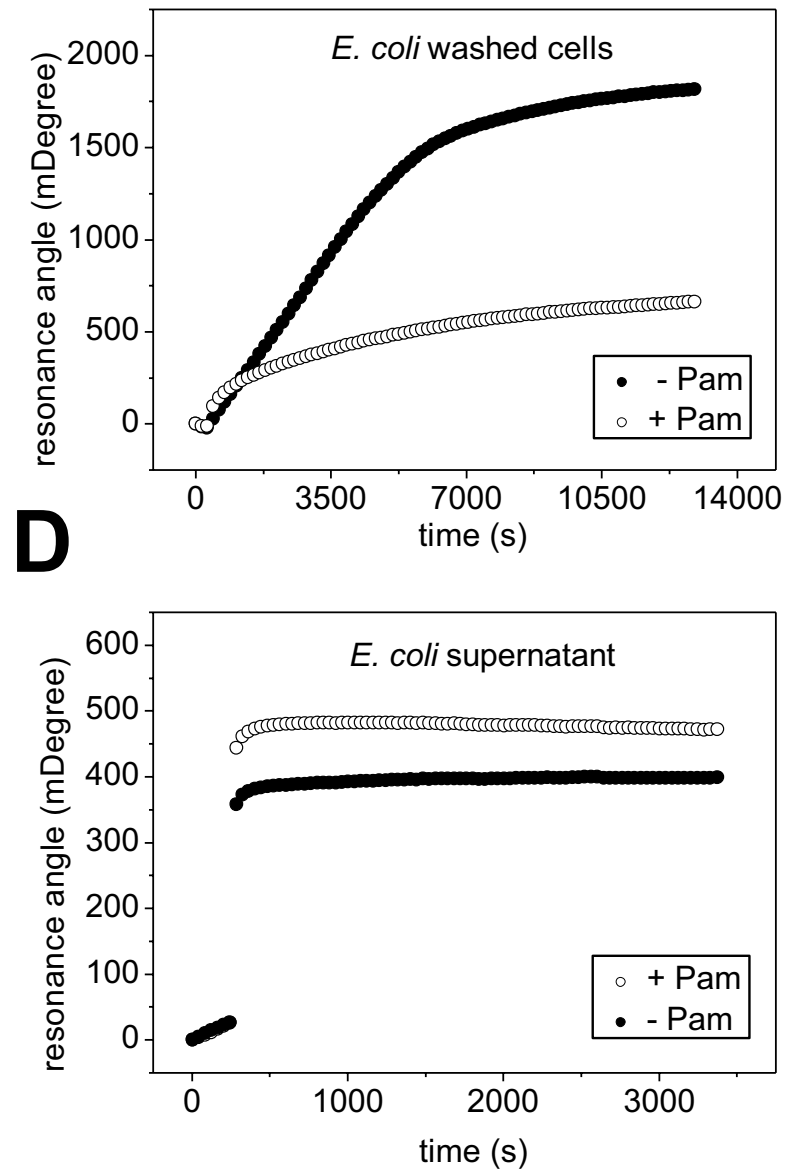

Figure 6 Surface plasmon resonance analysis of Pam-mediated adhesion on gold-coated glass probes. (A and B) Presence of the protein on the cell surface (washed cells) showed decreased adhesion to untreated gold surfaces in both TT01 rif and E. coli pBADpam (+Pam), when compared with the correspondent strains lacking Pam, TT01 pam and E. coli pBAD respectively (-Pam). (C and D) Supernatants from cultures expressing pam, TT01 rif and E. coli pBADpam (+Pam), showed more adhesion than those lacking the protein TT01 pam and E. coli pBAD (-Pam), indicating the ability of free Pam to adhere to surfaces.

mellonella, or that the different method of purification used by these authors preserved Pam's toxic phenotype.

The fact that we did not find any toxic effect of Pam towards insects, or any decrease in the efficiency of interaction with the symbiotic nematode, led us to investigate whether it was expressed during insect infection at all. Western blots with anti-Pam antibody against proteins isolated from infected insects suggested that Pam was first produced at $48 \mathrm{~h}$ and not earlier during the infection process, and that it was continuously produced for at least 11 days after insect death. Although the possibility exists that earlier production was below the detection limit of our assay, we note that $48 \mathrm{~h}$ coincides with death of the insect as determined by $\mathrm{LT}_{50}$ assays. These results indicate that Pam may play a role in occupancy of the insect cadaver rather than killing of the host and are consistent with a previous study of $P$. luminescens genes upregulated upon insect infection, in which pam (plu1537) was not present among the identified genes encoding several toxins and metabolic enzymes [17]. We have detected Pam both as secreted protein in the extracellular medium and bound to the EPS decorating the extracellular matrix surrounding cells. However, the observable structure of EPS/matrix is not significantly altered by the presence or absence of Pam. Although we observed no differences in mature biofilm, we found that Pam influences the early stages of bacterial attachment in hemolymph. SPR data from E. coli and P. luminescens cultures showed that membrane-bound Pam reduces the ability of cells to bind to the abiotic surface of the metallic 

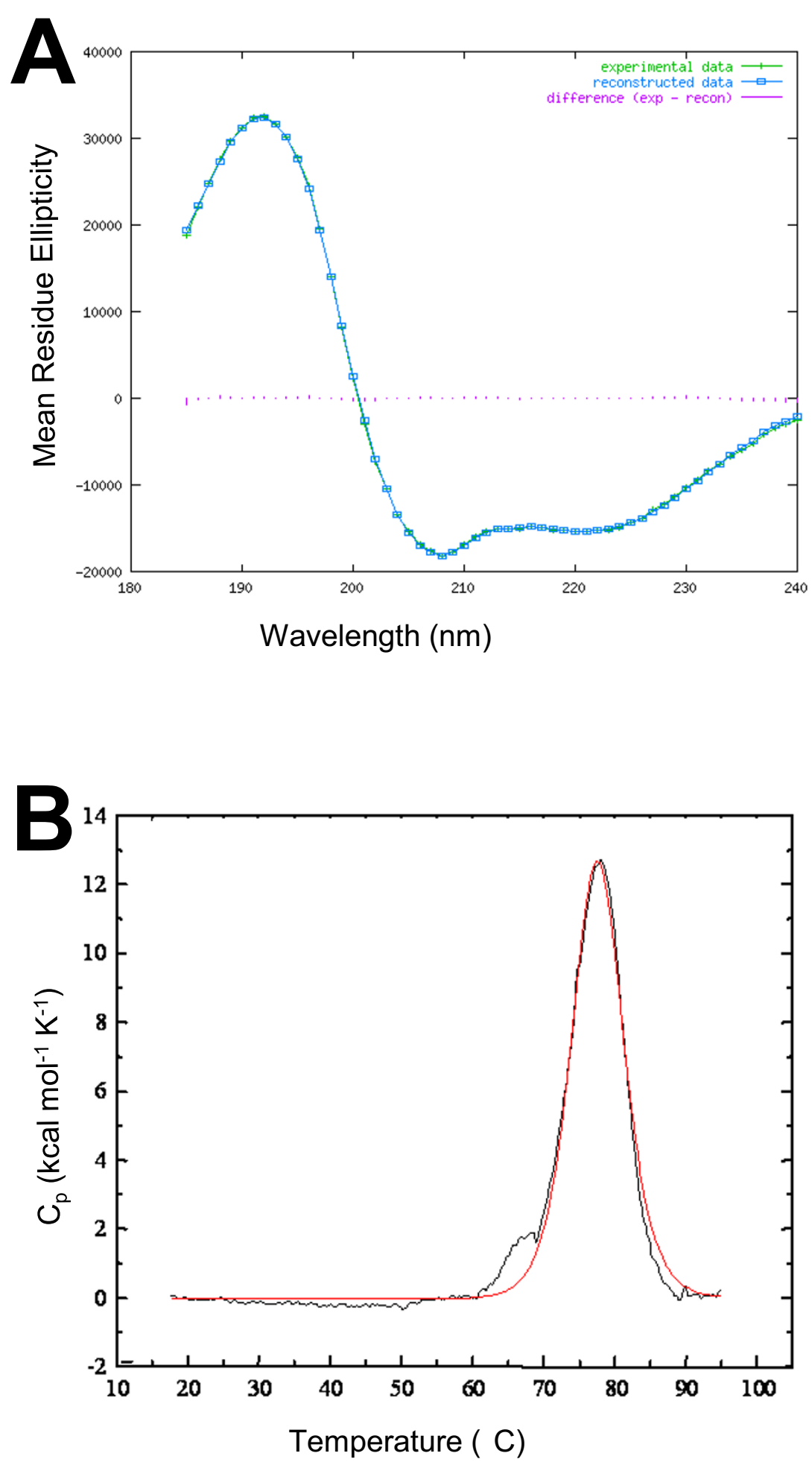

Figure 7 Structural properties of Pam. (A) Graphical output of far-UV CD data for Pam reveals that experimental data (green crosses) and calculated spectrum (blue boxes), derived from the calculated output secondary structure, show agreement. The difference spectrum (purple lines) is very close to zero throughout the wavelength range, indicating the goodness of fit of the structural predictions. The CD data indicate that Pam is largely helical $(58 \%)$, with only a small fraction of residues forming $\beta$-strands. (B) Thermal stability of Pam measured by differential scanning calorimetry. The normalised thermal transition curve (red line) shows energy uptake by Pam reached a peak (Tm) at $77.4^{\circ} \mathrm{C}$, representing the temperature at which $50 \%$ of the protein molecules are unfolded. This was almost identical after cooling the sample and repeating (black line). 
gold of the probe, and that the secreted protein itself is able to bind to this surface. The observation that Pam expression increases binding to an abiotic surface in insect blood is in contrast to the findings from the SPR analysis which suggest Pam lowers the adhesive properties of the cell. However these observed differences in attachment between the wild type and pam mutant in the hemolymph are not directly comparable with the SPR data. In the first case the cells are grown in the media where attachment is assessed and the combination of secreted and cell-bound Pam contributes to the phenotype, while for SPR we analyzed washed cells and supernatant separately. Furthermore, insect blood is a far more complex environment than the PBS used to resuspend the cells in the SPR study, so potential interactions of Pam and the bacterium with components of the insect immune system must be considered. Together, these data indicate that Pam is a secreted adhesive factor that modifies the surface properties of the cell, affecting the attachment process, specifically cell-to-cell and cell-to-surface attachment. Although it is important to note that attachment to abiotic substrata is not the same as attachment to living or devitalized tissue, we believe that this modification of adhesion by Pam may be involved in one or several processes key to the biology of the bacterium. For instance, once Photorhabdus has been regurgitated by IJ nematodes, it must colonize and invade the midgut [4] and this establishment of a biofilm, following attachment, is recognized as an important step in many microbial infections [18]. Since the effect of deleting Pam does not result in a complete gain or loss of attachment, the protein may allow some plasticity in colonization during the infection. Perhaps Pam allows adhesion to specific tissues or a transient attachment, or even to facilitate the release of cells from biofilms to colonize other tissues within the host, acting in an analogous manner to glycanases described other biofilm-forming bacteria [19].

The predicted amino acid sequence of Pam gives little clue to its role or of the potential structure that mediates its adhesive properties. To get an insight into the structure of Pam, we analyzed the protein with circular dichroism spectroscopy. Our far-UV CD data strongly indicate that Pam is a helical protein, with 5.5 helix segments per 100 residues and an average helix length of 10.5 residues. By contrast, only $8 \%$ of residues are expected to form $\beta$ strands. We obtained only very weak spectra for Pam in the near-UV wavelengths, but $1 \mathrm{D}{ }^{1} \mathrm{H}$ and $2 \mathrm{D}{ }^{1} \mathrm{H}-{ }^{15} \mathrm{~N}$ HSQC NMR spectra (data not shown) and high melting temperature from differential scanning calorimetry experiments confirm that the protein has well defined tertiary structure. A degree of tertiary structural prediction is available from the far-UV spectra, specifically the position of the spectral cross-over from positive to negative, and the magnitude of the negative maximum at 208 nm [20]. These both suggest that Pam is a $\alpha+\beta$ protein. Rather than having intermixed segments, such proteins have separate $\alpha$-helix and $\beta$-sheet-rich regions [21]. Interestingly, although Pam is not secreted at $37^{\circ} \mathrm{C}$ in $P$. asymbiotica, it shows thermal stability far beyond this. Differential scanning calorimetry revealed that the protein does not begin to thermally denature until heated to temperatures above $60^{\circ} \mathrm{C}$. The transition midpoint is $77.4^{\circ} \mathrm{C}$, suggesting that Pam is particularly thermostable for a protein produced by an organism considered to be psychrophilic [22]. In fact, this midpoint is approaching that seen in thermophilic bacteria and archaea [23-25]. Without high resolution structural analyses we are unable to explore precise contributions to the thermal stability of Pam, but the high $\alpha$-helix content is likely to be significant; thermostable proteins are richer in $\alpha$-helices than mesophilic proteins [26]. The observed ability of Pam to refold to its native conformation following denaturation may be biologically significant; this folding indicates that the protein can form its native structure in the absence of molecular chaperones, outside of the cell if it is secreted as an unfolded polypeptide. It is as yet not clear how Pam is secreted from the cell as we can detect no recognizable signal motifs, neither were found in Pit [10].

Finally, although the role of this highly secreted protein in Photorhabdus biology has not yet been completely elucidated, we have shown its possible relevance in cell attachment. Our findings indicate that Pam is a secreted adhesive factor of Photorhabdus that modifies attachment of cells to surfaces in biotic (hemolymp) and abiotic (SPR) conditions. Thus, it might be involved at different cell-cell and cell-surface adhesion stages during the insect host colonization, such as the production of a biofilm-like matrix on the insect gut, the spread of bacteria within the insect cadaver and potentially a resource protection role, binding to the insect tissues and preventing other saprophites from taking advantage of the biomass. The high levels of secretion and the degree of conservation within the genus are congruent with Pam modulating these important activities. Very little is known about Photorhabdus infections in humans, but a recent study has found that, unlike the extracellular growth of $P$. luminescens in insects [27], a clinical isolate of P. asymbiotica is a facultative intracellular pathogen when incubated with human macrophage-like cells [28]. Future studies may investigate what role if any Pam has in the infection of mammalian cells.

\section{Conclusions}

In this study we show that the highly abundant Pam protein is able to bind to exopolysaccharides and change the attachment properties of Photorhabdus. Deletion of pam altered bacterial adhesion to surfaces but did not cause a decrease in virulence towards Galleria mellonella larvae. 
However, Pam is produced during insect infection suggesting a role for this protein in the insect cadaver, possibly in the colonization of the insect body. Sequence analysis of pam in multiple isolates showed that it is ancestral and conserved in the genus Photorhabdus and thus deserves further investigations to clarify its role in the complex cycle of Photorhabdus biology.

\section{Methods \\ Bacterial strains, plasmids and culture conditions. DNA amplification and cloning}

The strains used in this study are: $P$. asymbiotica strain ATCC43949 [29], P. luminescens subspecies laumondii strain TT01 [30] and a wild-type spontaneous rifampicinresistant $P$. luminescens TT01rif (this study). A knock-out strain in the pam gene was constructed from TT01rif and named TT01pam. The pam gene was deleted from the chromosome by allelic exchange using the suicide vector pDS132 [31] and correct chromosomal deletion was confirmed by PCR and DNA sequencing of the region near the deleted gene. The pam knock-out strain grew similarly to the wild-type strain in rich and minimal media and insect plasma (filtered hemolymph). Escherichia coli EC100 (Epicentre Biotechnology, USA) was used for heterologous production of Pam. The pam gene was PCR amplified from $P$. asymbiotica ATCC43949 genomic DNA using the primers PamF: 5' TTAATCTTGGAATTCATTAAACACATT 3' and PamR: 5' TTAAAGCTTAGGTTACAATAGTATATTCT 3'. Using EcoRI and HinDIII restriction sites incorporated in the primers, the product was directionally cloned downstream of an arabinose-inducible promoter in the pBAD30 plasmid [32] to create the $\mathrm{pBAD}$ pam expression construct. Pam expression in E. coli EC100 containing pBADpam was induced by addition of $0.2 \%(\mathrm{w} / \mathrm{v}) \mathrm{L}$-arabinose overnight, and $E$. coli EC100 carrying pBAD30 empty vector was used as control. Cloned P. asymbiotica ATCC43949 pam in pET$28 \alpha$ (Novagen, USA) and expressed in E. coli BL21 (DE3) (Novagen, USA) was used for the feeding assays, and compared to E. coli EC100 carrying pET-28 $\alpha$ as control. Strains were grown with $250 \mathrm{rpm}$ agitation on LB medium [33] supplemented when required with $50 \mu \mathrm{g} \mathrm{ml}^{-}$ ${ }^{1}$ rifampicin, $100 \mu \mathrm{g} \mathrm{ml} \mathrm{m}^{-1}$ ampicillin, $10 \mu \mathrm{g} \mathrm{ml}-1$ tetracycline and $100 \mu \mathrm{g} \mathrm{ml} \mathrm{m}^{-1}$ kanamycin. E. coli strains were grown at $37^{\circ} \mathrm{C}, P$. luminescens TT01 and its derivatives at $28^{\circ} \mathrm{C}$ and $P$. asymbiotica at both temperatures depending on the assay. For pellicle assays [34] and biofilm in microscopy chambers (Ibidi) strains were grown statically in LB and Grace's/Schneider's insect media (Sigma).

Amplification of the $s 1$ gene from $P$. asymbiotica isolates was performed using the primers s1F: 5'TATGAATTCATAAGTAAGGAT 3' and s1R: 5' CGGTGTTTT AGTAAGCTTCTATCT 3'.
Two-dimensional gel electrophoresis, Western blot and Pam protein purification

From a starting overnight culture $\left(28^{\circ} \mathrm{C}\right)$ of $P$. asymbiotica ATCC43949, cultures were inoculated and grown for $24 \mathrm{~h}$ at $28^{\circ} \mathrm{C}$ and $37^{\circ} \mathrm{C}$ until early stationary phase. Proteins from both supernatants were phenol precipitated and resuspended in $150 \mu \mathrm{l}$ CDU buffer (4\% CHAPS, $130 \mathrm{mM}$ DTT and $9 \mathrm{M}$ Urea) containing $1 \times \mathrm{HALT}^{\mathrm{TM}}$ protease Inhibitor Cocktail Mix (Pierce, Thermo Fisher, UK). Samples were incubated for $2 \mathrm{~h}$ at room temperature, then centrifuged for $30 \mathrm{~min}$ at $88760 \times \mathrm{g}$. The RediPlate Protein Quantitation Kit (Molecular Probes, Invitrogen, UK) was used to quantify protein concentration in the samples and equivalent amounts of total proteins were loaded. A Multiphor II system (GE Healthcare, UK) was used for isoelectric focusing and horizontal SDS-polyacrylamide gel electrophoresis with Immobiline DryStrip gels and precast $12.5 \%$ SDS gels (GE Healthcare, UK), following the manufacturer's instructions. Gels were Coomassie stained and protein spots were excised and sent to the protein sequencing facility at the University of the West of England (Bristol, UK). The peptide sequences resulting from MALDI analysis of trypsin-digested proteins, were compared to all proteins in the SwissProt nonredundant database and to a database of predicted proteins from the P. asymbiotica ATCC43949 genome sequence [8].

A polyclonal anti-Pam antibody was raised in rabbits against the peptide KLIQDSIRLDQGEW (amino acid positions 28-41) from $P$. asymbiotica ATCC43949 by GenScript Corporation (USA). For Western blot, proteins were precipitated with $1 / 10$ volumes of $100 \%$ Trichloroacetic acid, separated by SDS-PAGE and transferred onto a Trans-Blot nitrocellulose membrane (BioRad, USA) using a Semi-Dry blotter (BioRad, USA). Membranes were incubated with 1/500 dilution of the anti-Pam antibody for $90 \mathrm{~min}$ and with $1 / 5000$ dilution of an anti-rabbit alkaline phosphatase conjugated secondary antibody for 90 min Alkaline phosphatase reaction with NBT-BCIP solution (Fluka, Sigma-Aldrich, USA) was used for development. To detect production of Pam in vivo, larvae of Galleria mellonella were injected with $20 \mu \mathrm{l}$ of diluted overnight cultures of either P. luminescens TT01 or $P$. asymbiotica ATCC43949, corresponding to 200 CFU. Infected insects were collected on successive days and crushed in lysis buffer, containing $125 \mathrm{mM}$ Tris $\mathrm{pH}$ 8.0, 4 $\mathrm{M}$ urea, $2 \%$ SDS, and 5\% $\beta$-mercaptoethanol $(1 \mathrm{ml}$ per insect). From each sample $10 \mu \mathrm{l}$ were loaded for SDSPAGE and analyzed by Western blotting.

For the purification of recombinant Pam: The pellet of 1 liter of $E$. coli cells producing Pam was resuspended in $10 \mathrm{ml}$ of buffer A (20 mM HEPES pH 7.5, $50 \mathrm{mM} \mathrm{NaCl})$ and lysed by sonication. The insoluble fraction was pelleted by centrifugation at $4^{\circ} \mathrm{C}, 16000 \times \mathrm{g}, 20 \mathrm{~min}$ and the 
resulting supernatant was diluted to $20 \mathrm{ml}$ with buffer A. This supernatant was loaded as $5 \mathrm{ml}$ fractions onto a $5 \mathrm{ml}$ Hitrap QFF anion exchange chromatography column (GE Healthcare, UK) equilibrated with: $3 \times$ column volumes (cv) buffer A, $3 \times$ cv buffer B (20 mM HEPES pH 7.5, $1 \mathrm{M}$ $\mathrm{NaCl}$ ) and $3 \times \mathrm{cv}$ buffer A. Chromatography was performed on an ÄKTA purifier (GE Healthcare, UK). The column was run at $0.8 \mathrm{ml} \mathrm{min}^{-1}$ with a $15 \mathrm{ml}$ wash after loading and a $5 \times \mathrm{cv}$ gradient from $5 \%$ to $100 \%$ buffer $\mathrm{B}$ to elute the protein. $1 \mathrm{ml}$ fractions were collected and $10 \mu \mathrm{l}$ samples were loaded for SDS-polyacrylamide gel electrophoresis. The Hitrap QFF step was followed by further anion exchange using a $1 \mathrm{ml}$ MonoQ column (GE Healthcare, UK). Fractions containing Pam were diluted fourfold with buffer $\mathrm{A}$ and $4 \mathrm{ml}$ were loaded after equilibration of the column. Pam was eluted with a gradient of 5\%-25\% buffer B over $8 \mathrm{cv}$, and fractions containing Pam were identified by SDS-PAGE. The estimated purity of Pam was 95\%.

\section{Extracellular-polysaccharide (EPS) crude extraction}

Cells grown on LB agar were harvested with a minimal volume of $0.9 \% \mathrm{NaCl}$ solution and EPS was detached by mixing for $15-20 \mathrm{~s}$ in a blender. Cells were pelleted and discarded, and 3 volumes of chilled acetone were added to the EPS-containing supernatant (previously concentrated to $30-40 \mathrm{ml}$ by freeze-drying). The mixture was kept at $-20^{\circ} \mathrm{C}$ overnight, centrifuged at $3000 \times$ g for 20 min and the pellet was dried and resuspended in a small volume $\left(10-20 \mathrm{ml} \mathrm{H}_{2} \mathrm{O}\right)$. This sample was ultra-centrifuged at $100000 \times \mathrm{g}$ for $4 \mathrm{~h}$ to precipitate the lipopolysaccharide fraction. The supernatant was removed and dialyzed overnight at $4^{\circ} \mathrm{CC}$. Samples were frozen at $-80^{\circ} \mathrm{C}$ for 4-6 h, and freeze-dried to concentrate. EPS suspensions $(2 \mathrm{mg} / \mathrm{ml})$ from TT01rif and TT01 pam were analysed by SDS-PAGE and Pam was detected by Western blot. A suspension of TT01rif EPS $(5 \mathrm{mg} / \mathrm{ml})$ was incubated with $1.6 \%$ SDS or salt $(0.5 \mathrm{M} \mathrm{KCl})$ or vortex for 4 mins before performing electrophoresis on native gel and Western blot.

\section{Virulence, toxicity and symbiosis assays}

For calculation of the $\mathrm{LT}_{50}$, or time taken for half of the initial population to die, approx 100 cells from overnight cultures of either TT01rif or TT01pam were injected per insect and 100 G. mellonella larvae were used per treatment. $\mathrm{LT}_{50}$ is the calculated time after injection at which $50 \%$ of the larval population was dead; differences in $\mathrm{LT}_{50}$ times represent different rates of killing. Scoring of insect death was carried out every $2 \mathrm{~h}$ between 44-52 h and 59$68 \mathrm{~h}$ post-injection. Oral toxicity was assessed with a standard feeding bioassay: $1 \mathrm{~cm}^{3}$ artificial wheat germ food blocks were supplemented with $200 \mu$ l of supernatant from sonicated and pelleted E. coli cultures or Phos- phate Buffered Saline (PBS) as control. All supplements were allowed to dry for 20 min under laminar flow. Two first-instar Manduca sexta neonate larvae were placed on each food block (12 larvae per treatment) and after 7 days incubation at $25^{\circ} \mathrm{C}$ the weight of each caterpillar was recorded. Tobacco hornworm $M$. sexta larvae were maintained on a wheat germ-based artificial diet [35] at $25^{\circ} \mathrm{C}$ with a photoperiod of $17 \mathrm{~h}$ light: $7 \mathrm{~h}$ dark. G. mellonella larvae were supplied by Livefood (UK).

For the assessment of symbiosis, infective juvenile (IJ) $H$. bacteriophora were propagated on a lawn of either TT01rif or TT01pam cells constitutively producing GFP. The proportion of IJs transmitting GFP-labeled bacteria was determined by fluorescence microscopy, as previously described [36].

\section{Transmission electron microscopy and hemolymph attachment assays}

For transmission electron microscopy (TEM), bacterial colonies grown on LB plates were fixed in $2.5 \%$ glutaraldehyde for $2 \mathrm{~h}$, washed in PBS and post-fixed in $1 \%$ osmium tetroxide for $1 \mathrm{~h}$. Samples were dehydrated in acetone and embedded in Spurr's resin (TAAB, Premix). Sections were cut with an ultra-microtome (Leica, Reichert Ultracut E) and stained with uranyl acetate and lead citrate before examination with a JEOL JEM 1200 EXII transmission electron microscope (JEOL Tokyo, Japan). For labeling Pam at the ultra-structural level, samples were dehydrated in ethanol and embedded in LR White acrylic resin before sectioning and incubation with the primary (anti-Pam) and secondary antibodies (goat antirabbit IgG conjugated with $10 \mathrm{~nm}$ gold particles).

For analysis of attachment in $5^{\text {th }}$ instar $M$. sexta plasma (filtered hemolymph), overnight cultures of TT01rif wildtype and TT01pam were diluted to $0.05 \mathrm{OD}_{600}$ and incubated at $28^{\circ} \mathrm{C}$ for $8 \mathrm{~h}$ without agitation in 24-well tissue culture plates on sterile circular glass coverslips. After $8 \mathrm{~h}$ the planktonic bacteria were gently aspirated and the coverslips were washed $3 \times$ with PBS. The coverslips were fixed with $300 \mu \mathrm{l}$ of $4 \%$ PBS-paraformaldehyde at $4{ }^{\circ} \mathrm{C}$ for $24 \mathrm{~h}$ and stained with 4',6-diamidino-2-phenylindole (DAPI). Coverslips were mounted with Miowiol (Calbiochem) and analyzed with fluorescent microscopy (Nikon Eclipse 90i, Japan). Cells count at $8 \mathrm{~h}$ was the average in 12 fields of vision at $60 \times$ magnification from triplicate samples for the TT01rif and the same sample size for the TT01pam mutant.

\section{Physicochemical methods}

Surface plasmon resonance (SPR) data were acquired using the Autolab ESPRIT (Eco Chemie, BV, The Netherlands). Measurements were made by following the variation in the reflected light minimum angle with time, which is indicative of the change in optical properties of 
the interface as bacteria attach. Glass disks with a thin gold coating (50 nm thick) were placed on a hemispherical prism using index match fluid ( $\mathrm{RI}=1.518$, Cargille), which ensured optical continuity. $50 \mu \mathrm{l}$ of PBS were added and the system was allowed to stabilise for four minutes before addition of $50 \mu \mathrm{l}$ of bacteria washed with PBS and adjusted to $6 \times 10^{8} \mathrm{CFU} \mathrm{ml}^{-1}$. The minimum angle was thus recorded with time. Measurements were made every three seconds for the duration of the experiment (until the SPR readings stabilized).

Purified Pam at $1 \mathrm{mg} \mathrm{ml}^{-1}$ concentration in $5 \mathrm{mM}$ phosphate buffer, pH 6.0 was used for circular dichroism (CD) spectroscopy and thermal analysis (differential scanning calorimetry, DSC). CD spectroscopy was performed by Sharon Kelly at the Department of Chemistry, University of Glasgow (UK). For CD in far-UV wavelengths, the sample was diluted to $0.383 \mathrm{mg} \mathrm{ml}^{-1}$ and data were collected from a $0.02 \mathrm{~cm}$ pathlength cuvette. For $\mathrm{CD}$ spectroscopy in the near-UV range, a $0.5 \mathrm{~cm}$ pathlength cuvette was used and Pam was diluted to $0.772 \mathrm{mg} \mathrm{ml}^{-1}$. The CD spectra, obtained below $550 \mathrm{~V}$, were analyzed using the CDSSTR variable selection method at the Dichroweb server [37,38]. Reference spectra set 3 [39], covering wavelengths $240-185 \mathrm{~nm}$, gave the most consistent results when the analysis was iterated. DSC was performed on a Microcal VP-DSC spectrometer at the BBSRC Microcalorimetry Service (Department of Chemistry, University of Glasgow, UK).

\begin{abstract}
Authors' contributions
RTJ, MSC and IV carried out experiments and drafted the manuscript. MRA, GY and $A U$ performed experiments and interpreted data. XMB, ATAJ and SB carried out the physicochemical experiments and interpreted data. UJP, SAJ and TAC participated in the acquisition, analysis and interpretation of data. RHffC and NRW obtained funding for and designed the research and critically revised the manuscript. All authors read and approved the final manuscript.
\end{abstract}

\section{Acknowledgements \\ This work was supported by the BBSRC grants Exploiting Genomics and RVA (BB/E021328/1) to RHffC and NRW, by the Wellcome Trust grant 076124 to S B, and by EMBEK1 grant (211436; EU- FP7) to ATAJ, RHffC and NRW. The authors would like to thank Sharon Kelly and the Microcalorimetry Service in the Department of Chemistry, University of Glasgow (Glasgow, UK), and staff at the Protein Sequencing facility, University of the West of England (Bristol, UK) for their help. We also thank Professor Stuart Reynolds for critical reading of the manuscript.}

\section{Author Details \\ 1Department of Biology and Biochemistry, University of Bath, Claverton Down, Bath, BA2 7AY, UK, 2Department of Chemistry, University of Bath, Claverton Down, Bath, BA2 7AY, UK, ${ }^{3}$ Centre for Electron Optical Studies, University of Bath, Claverton Down, Bath, BA2 7AY, UK, ${ }^{4}$ Department of Microbiology and Molecular Genetics, Michigan State University, East Lansing, Michigan, 48824, USA, 5 School of Biosciences, University of Exeter in Cornwall, Penryn, TR10 9EZ, UK and ${ }^{6}$ Department of Microbiology, University College Cork, Cork, Republic of Ireland}

Received: 9 June 2009 Accepted: 12 May 2010

Published: 12 May 2010
References

1. Forst S, Dowds B, Boemare N, Stackebrandt E: Xenorhabdus and Photorhabdus spp.: Bugs that kill bugs. Annual Review of Microbiology 1997, 51:47-72.

2. ffrench-Constant R, Waterfield N, Daborn PJ, Joyce S, Bennett H, Au C, Dowling A, Boundy S, Reynolds S, Clarke D: Photorhabdus: towards a functional genomic analysis of a symbiont and pathogen. FEMS Microbiology Reviews 2003, 26(5):433-456.

3. Ciche TA, Ensign JC: For the insect pathogen Photorhabdus luminescens, which end of a nematode is out? Applied and Environmental Microbiology 2003, 69(4):1890-1897.

4. Silva CP, Waterfield NR, Daborn PJ, Dean P, Chilver T, Au CPY, Sharma S, Potter U, Reynolds SE, ffrench-Constant RH: Bacterial infection of a model insect: Photorhabdus luminescens and Manduca sexta. Cellular Microbiology 2002, 4(6):329-339.

5. Gerrard JG, Joyce SA, Clarke DJ, ffrench-Constant RH, Nimmo GR, Looke DF, Feil EJ, Pearce L, Waterfield NR: Nematode symbiont for Photorhabdus asymbiotica. Emerging Infectious Diseases 2006, 12(10):1562-1564

6. Gerrard JR, Waterfield N, Vohra R, ffrench-Constant R: Human infection with Photorhabdus asymbiotica: an emerging bacterial pathogen. Microbes and Infection 2004, 6(2):229-237.

7. Turlin E, Pascal G, Rousselle JC, Lenormand P, Ngo S, Danchin A, Derzelle S: Proteome analysis of the phenotypic variation process in Photorhabdus luminescens. Proteomics 2006, 6(9):2705-2725.

8. Wilkinson P, Waterfield NR, Crossman C, Corton C, Sanchez-Contreras M, Vlisidou I, Barron A, Bignell A, CLark L, Doggett J, et al:: Comparative genomics of the emerging human pathogen Photorhabdus asymbiotica with the insect pathogen Photorhabdus luminescens. BMC Genomics 2009, 10:

9. Moellenbeck DJ, Peters ML, Bing JW, Rouse JR, Higgins LS, Sims L, Nevshemal T, Marshall L, Ellis RT, Bystrak PG, et al.: Insecticidal proteins from Bacillus thuringiensis protect corn from corn rootworms. Nature Biotechnology 2001, 19(7):668-672.

10. Li M, Wu G, Liu C, Chen Y, Qiu L, Pang Y: Expression and activity of a probable toxin from Photorhabdus luminescens. Mol Biol Rep 2008.

11. Ryder C, Byrd M, Wozniak DJ: Role of polysaccharides in Pseudomonas aeruginosa biofilm development. Curr Opin Microbiol 2007, 10(6):644-648

12. Kelly SM, Jess TJ, Price NC: How to study proteins by circular dichroism. Biochimica et Biophysica Acta (BBA) - Proteins and Proteomics 2005, 1751(2):119-139.

13. Mao D, Wachter E, Wallace BA: Folding of the mitochondrial proton adenosine triphosphatase proteolipid channel in phospholipid vesicles. Biochemistry 1982, 21(20):4960-4968.

14. Waterfield NR, Sanchez-Contreras M, Eleftherianos I, Dowling A, Yang G, Wilkinson P, Parkhill J, Thomson N, Reynolds SE, Bode HB, et al:: Rapid Virulence Annotation (RVA): Identification of virulence factors using a bacterial genome library and multiple invertebrate hosts. Proceedings of the National Academy of Sciences 2008, 105(41):15967-15972.

15. Ellis RT, Stockhoff BA, Stamp L, Schnepf HE, Schwab GE, Knuth M, Russell J, Cardineau GA, Narva KE: Novel Bacillus thuringiensis Binary Insecticidal Crystal Proteins Active on Western Corn Rootworm, Diabrotica virgifera virgifera LeConte. App/ Environ Microbiol 2002, 68(3):1137-1145.

16. Schnepf HE, Lee S, Dojillo J, Burmeister P, Fencil K, Morera L, Nygaard L, Narva KE, Wolt JD: Characterization of Cry34/Cry35 binary insecticidal proteins from diverse Bacillus thuringiensis strain collections. Applied and Environmental Microbiology 2005, 71(4):1765-1774.

17. Munch A, Stingl L, Jung K, Heermann R: Photorhabdus /uminescens genes induced upon insect infection. BMC Genomics 2008, 9:229.

18. Costerton JW, Stewart PS, Greenberg EP: Bacterial biofilms: A common cause of persistent infections. Science 1999, 284(5418):1318-1322.

19. Finnie C, Zorreguieta A, Hartley NM, Downie JA: Characterization of Rhizobium leguminosarum exopolysaccharide glycanases that are secreted via a type I exporter and have a novel heptapeptide repeat motif. J Bacterio/ 1998, 180(7):1691-1699.

20. Manavalan P, Johnson WCJ: Sensitivity of circular dichroism to protein tertiary structure class. Nature 1983, 305:831-832

21. Levitt $M$, Chothia C: Structural patterns in globular proteins. Nature 1976, 261(5561):552-558. 
22. Bowen DJ, Rocheleau TA, Grutzmacher CK, Meslet L, Valens M, Marble D, Dowling AJ, ffrench-Constant $\mathrm{RH}$, Blight MA: Genetic and biochemical characterization of PrtA, an RTX-like metalloprotease from Photorhabdus. Microbiology 2003, 149:1581-1591.

23. Shallom D, Golan G, Shoham G, Shoham Y: Effect of dimer dissociation on activity and thermostability of the alpha-glucuronidase from Geobacillus stearothermophilus: dissecting the different oligomeric forms of family 67 glycoside hydrolases. Journal of Bacteriology 2004, 186(20):6928-6937.

24. Li WT, Grayling RA, Sandman K, Edmondson S, Shriver JW, Reeve JN: Thermodynamic stability of archaeal histones. Biochemistry 1998, 37(30):10563-10572.

25. McCrary BS, Edmondson SP, Shriver JW: Hyperthermophile protein folding thermodynamics: differential scanning calorimetry and chemical denaturation of Sac7d. Journal of Molecular Biology 1996, 264(4):784-805.

26. Kumar S, Tsai CJ, Nussinov R: Factors enhancing protein thermostability. Protein Engineering 2000, 13(3):179-191.

27. Brugirard-Ricaud K, Duchaud E, Givaudan A, Girard PA, Kunst F, Boemare $\mathrm{N}$, Brehelin M, Zumbihl R: Site-specific antiphagocytic function of the Photorhabdus luminescens type III secretion system during insect colonization. Cellular Microbiology 2005, 7(3):363-371.

28. Costa SCP, Girard PA, Brehelin M, Zumbihl R: The Emerging Human Pathogen Photorhabdus asymbiotica Is a Facultative Intracellular Bacterium and Induces Apoptosis of Macrophage-Like Cells. Infection and Immunity 2009, 77(3):1022-1030.

29. Farmer JJ, Jorgensen JH, Grimont PAD, Akhurst RJ, Poinar GO, Ageron E, Pierce GV, Smith JA, Carter GP, Wilson KL, et al: Xenorhabdus-Luminescens (DNA Hybridization Group-5) from Human Clinical Specimens. Journal of Clinical Microbiology 1989, 27(7):1594-1600.

30. Fischer-Le Saux M, Viallard V, Brunel B, Normand P, Boemare NE: Polyphasic classification of the genus Photorhabdus and proposal of new taxa: $P$. luminescens subsp. luminescens subsp. nov., P. luminescens subsp. akhurstii subsp. nov., P. luminescens subsp. laumondii subsp. nov., $P$. temperata sp. nov., $P$. temperata subsp. temperata subsp. nov. and P. asymbiotica sp. nov. Int J Syst Bacteriol 1999, 49(Pt 4):1645-1656.

31. Philippe N, Alcaraz JP, Coursange E, Geiselmann J, Schneider D: Improvement of pCVD442, a suicide plasmid for gene allele exchange in bacteria. Plasmid 2004, 51(3):246-255

32. Guzman LM, Belin D, Carson MJ, Beckwith J: Tight regulation, modulation, and high-level expression by vectors containing the arabinose PBAD promoter. J Bacterio/ 1995, 177(14):4121-4130.

33. Bertani G: Studies on lysogenesis. I. The mode of phage liberation by Iysogenic Escherichia coli. J Bacteriol 1951, 62(3):293-300.

34. Spiers AJ, Bohannon J, Gehrig SM, Rainey PB: Biofilm formation at the airliquid interface by the Pseudomonas fluorescens SBW25 wrinkly spreader requires an acetylated form of cellulose. Mol Microbiol 2003 50(1):15-27

35. Reynolds SE, Nottingham SF, Stephens AE: Food and Water Economy and Its Relation to Growth in 5th-Instar Larvae of the Tobacco Hornworm, Manduca-Sexta. Journal of Insect Physiology 1985, 31(2):119-127.

36. Ciche TA, Kim KS, Kaufmann-Daszczuk B, Nguyen KC, Hall DH: Cell Invasion and Matricide during Photorhabdus luminescens Transmission by Heterorhabditis bacteriophora Nematodes. Appl Environ Microbiol 2008, 74(8):2275-2287.

37. Whitmore L, Wallace BA: DICHROWEB, an online server for protein secondary structure analyses from circular dichroism spectroscopic data. Nucleic Acids Research 2004:W668-673.

38. Lobley A, Whitmore L, Wallace BA: DICHROWEB: an interactive website for the analysis of protein secondary structure from circular dichroism spectra. Bioinformatics 2002, 18(1):211-212.

39. Sreerama N, Woody RW: Estimation of protein secondary structure from circular dichroism spectra: comparison of CONTIN, SELCON, and CDSSTR methods with an expanded reference set. Anal Biochem 2000, 287(2):252-260

doi: $10.1186 / 1471-2180-10-141$

Cite this article as: Jones et al., Photorhabdus adhesion modification protein (Pam) binds extracellular polysaccharide and alters bacterial attachment BMC Microbiology 2010, 10:141

\section{Submit your next manuscript to BioMed Central and take full advantage of:}

- Convenient online submission

- Thorough peer review

- No space constraints or color figure charges

- Immediate publication on acceptance

- Inclusion in PubMed, CAS, Scopus and Google Scholar

- Research which is freely available for redistribution

Submit your manuscript at www.biomedcentral.com/submit
C BioMed Central 